TOWARDS FREE TRADE IN AGRICULTURE 


\section{THE INTERNATIONAL INSTITUTE FOR APPLIED SYSTEMS ANALYSIS}

is a nongovernmental research institution, bringing together scientists from around the world to work on problems of common concern. Situated in Laxenburg, Austria, IIASA was founded in October 1972 by the academies of science and equivalent organizations of twelve countries. Its founders gave IIASA a unique position outside national, disciplinary, and institutional boundaries so that it might take the broadest possible view in pursuing its objectives:

To promote international cooperation in solving problems arising from social, economic, technological, and environmental change

To create a network of institutions in the national member organization countries and elsewhere for joint scientific research

To develop and formalize systems analysis and the sciences contributing to it, and promote the use of analytical techniques needed to evaluate and address complex problems

To inform policy advisors and decision makers about the potential application of the Institute's work to such problems

The Institute now has national member organizations in the following countries:

\section{Austria}

The Austrian Academy of Sciences

\section{Bulgaria}

The National Committee for Applied

Systems Analysis and Management

\section{Canada}

The Canadian Committee for IIASA

Czechoslovakia

The Committee for IIASA of the

Czechoslovak Socialist Republic

Finland

The Finnish Committee for IIASA

France

The French Association for the

Development of Systems Analysis

German Democratic Republic

The Academy of Sciences of the German

Democratic Republic

Federal Republic of Germany

Association for the Advancement

of IIASA

\section{Hungary}

The Hungarian Committee for Applied Systems Analysis

Italy

The National Research Council

Japan

The Japan Committee for IIASA

Netherlands

The Foundation IIASA-Netherlands

\section{Poland}

The Polish Academy of Sciences

\section{Sweden}

The Swedish Council for Planning and Coordination of Research

Union of Soviet Socialist Republics The Academy of Sciences of the Union of Soviet Socialist Republics

United States of America

The American Academy of Arts and

Sciences 


\section{Towards Free Trade in Agriculture}

by

\section{KIRIT S. PARIKH, GÜNTHER FISCHER, KLAUS FROHBERG, ODD GULBRANDSEN}

Food and Agriculture Program (FAP)

International Institute for Applied Systems Analysis (IIASA)

Laxenburg, Austria

1988 Springer-Science+Business Media, B.V.

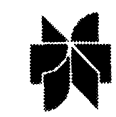




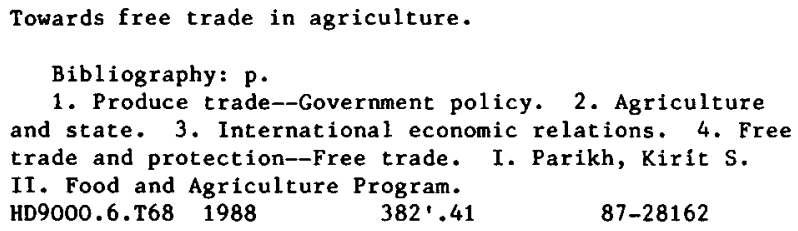

ISBN 978-94-017-3560-5 ISBN 978-94-017-3558-2 (eBook)

DOI 10.1007/978-94-017-3558-2

\section{Copyright}

(C) 1988 by Springer Science+Business Media Dordrecht

Originally published by the Martinus Nijhoff Publishers in 1988 Softcover reprint of the hardcover 1st edition 1988

All rights reserved. No part of this publication may be reproduced, stored in a retrieval system, or transmitted in any form or by any means, mechanical, photocopying, recording, or otherwise, without the prior written permission of the publishers, Springer-Science+Business Media, B.V. 


\section{Preface}

Agriculture seems to be a difficult sector to manage for most governments. Developing countries face tough dilemmas in deciding on appropriate price policies to stimulate food production and maintain stable, preferably low, prices for poor consumers. Governments in developed countries face similar difficult decisions. They are called upon to give income guarantees to farmers whose incomes are unstable and relatively low when compared to those in the nonagricultural sector. These guarantees often lead to ever-increasing budgetary outlays and unwanted agricultural surpluses.

High prices make new investments and the application of new technologies more attractive than world prices warrant, and a process is set in motion where technological innovation attains a momentum of its own, in turn requiring price policies that maintain their rates of return.

Surpluses are disposed of with subsidies in domestic markets or in the international market. Price competition reduces the market share of other exporters, who may be efficient producers, unless they are willing to engage in subsidy competition. This lowers export earnings and farm incomes or depletes the public resources of developing countries that export competing products. Retaliatory measures have led to frictions and further distortions of world prices.

Every so often the major agricultural exporters - the USA, the EC, Australia, or Canada - accuse one another of unfair intervention. Though they have agreed to discuss agricultural trade liberalization under GATT negotiations, if anything, the expenditure on farm support has continued to increase in both the EC and the USA.

Some developing countries do benefit from the subsidized disposal of surplus cereals on the world market. This, however, might be only a short-term gain. Low prices are a disincentive to their own producers and lead, in the long run, to an unsustainable dependence on imports, as appears to be the case in many parts of Africa. Also, these benefits of cheap cereals may not offset the loss of markets, such as the sugar market, which is important to a large number of developing countries.

Against that background and in the light of the fact that many countries have agreed to discuss agricultural trade liberalization under GATT, it is important to assess the consequences of agricultural trade liberalization. It should increase efficiency at the global level as countries adjust their production more in line with their comparative advantages. However, in the absence of 
compensating transfers, some countries may lose under liberalization. An assessment of efficiency gains at the global level and gains and losses of countries can provide some insight into the degree to which their own production and trade have become distorted and how large the adjustment costs may be. Several questions are relevant here: what if the developed market economies remove border protection? But also: what consequences can be expected from the removal of border protection by developing countries only? (This is an issue that can be usefully analyzed as it belongs to the regular package of adjustment policies recommended by the World Bank and the IMF.) What would be the impact of simultaneous liberalization by all market economies? Who would gain and who would lose?

This book reports on a study that explored these questions using a system of empirically estimated national agricultural policy models linked together through trade and capital transfers. A general equilibrium approach is followed for both the national models and the international linkage. Thus, behavioral responses of consumers and producers, as well as the responses of government policies to changes in world market conditions, are accounted for.

We call this system of models the Basic Linked System (BLS). It consists of 18 national models, two models of regions - namely, the EC and the Council for Mutual Economic Assistance (CMEA) - and 14 somewhat simpler models of groups of countries. Together these cover all the nations of the world. We believe that the BLS is particularly suited - at least, better than any other existing analytic tool - for the analysis of issues related to agricultural trade liberalization and self-sufficiency.

The present study differs from other available studies on trade liberalization in combining all the following features: a general equilibrium approach is applied to both the national and international levels; most of the parameters are empirically estimated; a number of agricultural commodities are distinguished; nations are distinguished; and a rich variety of policy instruments for national governments is permitted, including tariffs, trade, quotas, taxes, transfers, and stock operations. The existence of these features can significantly alter policy conclusions derived from the analysis.

The development of BLS, without the use of which this study could not have been made, has involved many people in the Food and Agriculture Program (FAP) at the International Institute for Applied Systems Analysis (IIASA) and its network of collaborating institutions. As with any large project that takes many years, it is virtually impossible to give individual credit to all those who have contributed; yet one must try. The program core of FAP consisted of the following:

Kirit Parikh (Program Leader 1980-1986)

Ferenc Rabar (Program Leader 1976-1980)

Günther Fischer

Klaus Frohberg

Michiel Keyzer 
The members of the program core have been responsible for all aspects of model development and analysis. Conception of the system and development of the algorithms was done mainly by Michiel Keyzer.

Other program participants who have contributed to development of various aspects of the BLS are: Michael Abkin, Csaba Csaki, Tom Christensen, Odd Gulbrandsen, Janos Hrabovszky, Gerhard Krömer, Bozena Lopuch, Douglas Maxwell, Donald Mitchell, Jan Morovic, Nanduri Narayana, Martha Neunteufel, Karl Ortner, Gerald Robertson, Mahendra Shah, Ulrike Sichra, Ralph Seeley, T.N. Srinivasan, Eric Wailes, David Watt, Chris Wolf, and Laszlo Zeold.

A large number of others were involved in the program, particularly for the development of detailed national policy analysis models for specific countries. Though several of these models have been used in a number of countries, not all of them are currently available as a part of the BLS. Naturally the study has benefited from the country-specific knowledge and evaluations made by many of these researchers.

Other researchers have also commented constructively on various aspects of the system methodology and behavior. Among them are, in alphabetical order, the following: Reinaldo Adams, Harold Carter, Hartwig de Haen, U. Färber, Bruce Gardner, Erik Geyskens, John Graham, John Guise $\dagger$, Werner Güth, Bruce Huff, Vladimir Iakimets, Raul Jorge, Werner Kiene, F. Desmond McCarthy, Constantine Meghir, Haruo Onishi, Brian Parmenter, Pierpaolo Pierani, Leon Podkaminer, Todor Popov, Alberto Portugal, Allan N. Rae, Bruno Raguet, Sudhaker Rao, E. George Rossmiller, Kozo Sasaki, Stephen Schmidt, Peter Michael Schmitz, Jörg-Volker Schrader, Taisto Sonnenson, Valter Jose Stülp, Stefan Tangermann, Robert Thompson, Anton Timman, Wouter Tims, Paul J.J. Veenendaal, Anton Visser, Matthias von Oppen, Jean Waelbroeck, Anton Wagemeyer, and Cheryl Williamson.

In designing our approach to the study of trade liberalization we have benefited from the suggestions and comments of Bruce Gardner, Bruce Huff, Michiel Keyzer, T.N. Srinivasan, and Robert Thompson.

We have also benefited from the constructive comments of T. N. Srinivasan and Wouter Tims, who read the various drafts of this report.

It is my privilege to gratefully acknowledge the many contributions of all my colleagues at IIASA and the various program participants in the many collaborating institutions. A great deal of credit goes to them; but the authors of this report bear all the responsibility.

Finally, the authors want to acknowledge with thanks Lilo Roggenland for typing and correcting numerous drafts of this report.

Kirit Parikh

Program Leader, FAP International Institute for Applied Systems Analysis 


\section{Contents}

Preface $\quad$ v

1. Issues in Trade Liberalization 1

1.1. The setting 1

1.2. Why study agricultural trade liberalization? $\quad 7$

1.3. Issues addressed, outline of the approach, and distinguishing features of the study 11

1.4. Plan of the book 13

1.5. A guide for the reader 14

2. Agricultural Distortions: Magnitudes and Driving Forces 15

2.1. The general pattern of distortion 16

2.2. Driving forces behind agricultural distortions 22

3. The Analytical Approach $\quad 27$

3.1. The analytical framework needed for assessing impacts of trade liberalization - and our approach $\quad 27$

3.2. The BLS for national models $\quad 29$

3.3. The scheme of analysis 38

3.4. Summary and concluding comments 54

4. A Perspective on Agriculture until 2000: The Reference Scenario 55

4.1. Specification of the reference scenario 55

4.2. Growth performance over $1980-2000$ in the reference scenario 56

4.3. World market price trends in the reference scenario 60

4.4. Shifts in demand and production structures $\quad 67$

$\begin{array}{ll}\text { 4.5. Changing patterns of trade } & 71\end{array}$

4.6. Tariff in the reference scenario 76

4.7. Agriculture in the national economies 81

4.8. Welfare and hunger in the reference scenario 83

4.9. Concluding observation $\quad 85$ 
5. Reducing Trade Distortions in OECD Countries $\quad 87$

$\begin{array}{ll}\text { 5.1. Introduction } & 87\end{array}$

5.2. Higher world market prices under trade liberalization by the OECD

5.3. Changes in growth patterns of national economies $\quad 89$

5.4. Changes in production and trade in the world under OECD trade liberalization

5.5. What causes changes in world market prices of agricultural commodities?

5.6. Welfare gains and distributions from OECD trade liberalization

5.7. Impact on farm incomes and parity

5.8. Previous studies of agricultural trade liberalization by OECD countries

5.9. Summary of results and policy implications

6. Unilateral Trade Liberalization by the EC or the USA

6.1. Unilateral trade liberalization by the EC

6.2. Unilateral trade liberalization by the USA

6.3. A brief comparison of both unilateral trade liberalization scenarios (F-EC and F-USA) with overall OECD trade liberalization (F-OECD)

7. Trade Liberalization by Developing Countries

7.1. Relevance of the scenario

7.2. The specification of the scenario

7.3. Impact on the world market

7.4. Price changes and growth patterns at national levels $\quad 174$

7.5. Changes in production and trade patterns

7.6. Impact on welfare of agricultural trade liberalization by the developing countries

7.7. Summary and policy implications

8. Agricultural Trade Liberalization by All Market Economies 193

8.1. The scenario F-ALLME

8.2. Changes under agricultural trade liberalization by all market economies

8.3. Changes in patterns of production and trade 207

8.4. Main factors behind the changes of the world market prices 213

8.5. Nominal versus real tariff equivalents 220

8.6. Welfare gains and their distribution from agricultural trade liberalization by all market economies 
9. Findings and Policy Conclusions $\quad 227$

9.1. Small global impact of agricultural trade liberalization 228

9.2. Should OECD countries liberalize agricultural trade? 229

9.3. Do the current protective agricultural policies of the rich countries help or hinder the poor?

9.4. Should the developing countries liberalize their agricultural trade?

232

9.5. Development of the global agricultural system 233

$\begin{array}{ll}\text { 9.6. Need for the analytical approach } & 233\end{array}$

9.7. Global interdependence, trade policy negotiations, $\begin{array}{ll}\text { and the usefulness of the BLS } & 234\end{array}$

A1. Economic Theory of Trade Liberalization: Some Selected Results 237

A2. Modes, Means, and Estimates of Protection 251

A3. The Impact of Trade Liberalization from the Country Perspective 283

A4. Countries and Groupings 345

$\begin{array}{ll}\text { References } & 353\end{array}$ 